\title{
A STRUCTURAL RELATIONSHIP BETWEEN TQM PRACTICES AND ORGANIZATIONAL PERFORMANCE WITH REFERENCE TO SELECTED AUTO COMPONENT MANUFACTURING COMPANIES
}

\author{
Dr. A. S. Sathish Kumar \\ Assistant Professor, Knowledge Business School, \\ KIOT Campus, Salem. Tamilnadu, India.
}

\section{Dr. J. Shanmuganathan}

Associate Professor, Bengaluru School of Management Studies,GITAM (Deemed to be University), Bengaluru campus, Bengaluru, Karnataka, India.

\begin{abstract}
Total Quality Management (TQM) is a holistic management philosophy of continuously improving the product / service / process quality by focusing on the customer needs and expectation to enhance customer satisfaction and organizational performance. Quality management is a systematic way of guaranteeing that organized activities happen the way they are planned. TQM as long-term commitment to new learning and new philosophy is required of any management that seeks transformation. The objective is to study the TQM practices and their influence on organizational performance in selected auto component manufacturing companies located in the state of Tamilnadu, India and to find out the relationship of TQM practices on commitment and performance of the organization as a whole. TQM practices like management participation, team work, employee empowerment, training and development, process quality management, supplier quality management, employee encouragement and quality culture significantly influences the employee commitment. In turn employee commitment on TQM practices have significant influences on employee performance and quality performance as well.
\end{abstract}

Keywords: TQM Practices, Quality Performance, Employee Performance, Organizational Commitment, Employee Commitment

Cite this Article: Dr. A. S. Sathish Kumar and Dr. J. Shanmuganathan, A Structural Relationship between TQM Practices and Organizational Performance with Reference to Selected Auto Component Manufacturing Companies, International Journal of Management, 10 (5), 2019, pp. 99-108.

http://iaeme.com/Home/issue/IJM?Volume=10\&Issue $=5$ 


\section{INTRODUCTION}

TQM practices are quite important in organization today to interconnect the quality practices with commitment and involvement of organizational stakeholders to achieve their operational excellence. Indian Auto component manufacturing sector focuses more on quality practices for sustaining its competition with global automobile market. Many auto component manufacturing companies of Japan, USA and Europe have gained or regained their competitive advantage based on TQM principles. In current scenario, implementation of TQM could overcome the quality challenges like adopting suitable quality practices, improving quality performance, following ISO procedures and so on which are faced by an organization. In contrary, organizational performance is defined as the measurable consequences of decisions and operations which signify efficiency, profitability and growth rate. Accordingly, an organizations performance show an evaluation pattern in order to be aware of the rate at which performance and specified quality are excelled in dynamic and competitive environment.

\section{RELATIONSHIP OF TQM PRACTICES, COMMITMENT AND PERFORMANCE}

TQM is now becoming recognized as a generic management tool and similar practice can be adoptable to service and public sector organizations. There are a number of evolutionary quality standards in different sectors created for their own improvement and betterment of practices followed in the respective sector. TQM, is a method by which management and employees can become involved in the continuous improvement of the production of goods and services. It is a combination of quality and management tools aimed at increasing business and reducing losses due to wasteful practices. It is a management philosophy that seeks to integrate all the organizational functions like marketing, finance, design, engineering, and production, customer service and so on.to focus the customer needs and organizational objectives.

Now a days, the organization follows a quality practices like 5S, Kaizen, Six Sigma, Lean methodologies and so on for improving their process quality and reduction of waste. TQM is a philosophy that underlines the structural transformation of organizational and employee commitment. According to Wilkinson (1992), an organization oriented towards TQM should remove barriers within the firm in order to promote high-trust relationships. Therefore efforts should be driven at encouraging employee reliance on customer relationships, through which people view their colleagues as customers and linked via a chain of internal customer relationships to the final (external) customer (Wilkinson et al., 1998). The introduction of TQM also requires the promotion of a collective commitment to quality objectives by all organizational members (Oakland, 2000). Employee commitment to the organization is essential for a TQM strategy to succeed, as it favours their tendency to work within their own authority and to contribute with feasible proposals to solve problems (Pun et al., 2001).

\section{LITERATURE REVIEW}

Literature reviews shows that TQM implementation is one of the mandatory activity of an organization in worldwide. It also determines the importance of cultural changes that impose in organization after the TQM Implementation. The literature also examined the relationship that lies between management and performance indicators by implementing TQM practices in an organization. TQM practices are illustrated in several studies and that can be adopted in different sector based on policies and procedures followed in their respective countries. Empirical reviews on TQM practices and their effects on performance are discussed in this section.

Faisal Talib, et al., (2010) attempted to identify and propose a list of "vital few" TQM critical Success Factors (CSFs) for the benefit of researchers and service industry practitioners. 
A quality tool "Pareto analysis" is used to sort and arrange the CSFs according to the order of criticality. The objectives of the study are to apply a Pareto analysis quality tool and to sort the CSFs in descending order according to the frequencies of their occurrences obtained from the present literature review. The methodology adopted is in-depth literature review of those studies that focus on QM/TQM CSFs/practices either in service industries or in manufacturing and service industries both, and the studies that correlate the TQM CSFs with performance outcomes based on which a few vital CSFs are identified and reported. Pareto analysis is a statistical technique in decision making that is used for the selection of a limited number of tasks that produce significant overall effect. The study results would help in the successful implementation of TQM program in organizations with top management support and commitment in implementing TQM practices and continuous involvement and innovation that happen in service industries.

Cemal Zehira, et al., (2012) have investigated whether TQM activities affect quality and innovative performance and defined the effectiveness of these performance components. Accordingly, hypotheses are developed and in order to test the research model, data are collected through a survey in Marmara Region. A survey conducted among mid- and upperlevel managers of companies in the Marmara region from various size manufacturing $(79.6 \%)$, information technology $(6.2 \%)$ and service (14.2) sector companies. While $54.7 \%$ of the respondent companies are small and medium-scale and $45.3 \%$ are large-scale. In addition to that $15.7 \%$ of companies are international, $8 \%$ of them are regional and $76.2 \%$ of companies are national. Totally 261 valid questionnaire from 104 companies are used for empirical analysis of the study. The findings shows significant and positive relationship among TQM activities, quality and innovation performance. Finally, the study highlights that the two performance indicators such as quality and innovative based approach to management dimensions are found to be an important TQM component to withstand firm's performance.

Esam and Abdul (2012) have attempted to review the role and impact of top management commitment and leadership upon TQM in service organizations in Malaysia, and to come out with a conceptual framework model. A total of 15 related studies are selected and reviewed from well-known electronic academic resources and databases like Emerald insight, Elsevier Science direct and Scopus. A conceptual framework is developed according to the finding and theoretical dimensions of the study. The outcome described the views of literature in this field and helps to understand the role of top management leadership and commitment in TQM practices. It shows the opinion and perspectives of researcher towards the role of top management leadership and commitment within Malaysian service sector organizations. However, it is difficult to find out exactly how the role is important and in what way it's linked to other TQM practices.

Schmidt, et al., (2013) have investigated the existence of soft and hard TQM factors in the EFQM excellence model at first and secondly, their impact upon key business results. The EFQM model has been used as a framework model as it is the TQM implementation referent that is most widespread and accepted in the specialized literature. Factorial analysis is utilized to determine the existence of the soft and hard TQM factors in the EFQM model and regression analysis is used to establish the impact of the factors identified on the business' key results. A sample of 116 firms have been subjected to complete assessment processes like self-assessment and external assessment according to the EFQM model. The key findings of the study suggest that the factorial analysis has grouped EFQM excellence model into five factors with major classification of soft and hard TQM factors. Regression analysis indicates the significant influence of hard and soft factors of TQM with business results. The result also determines the strong influence and relationship between soft and hard factors of TQM. 
José, et al., (2014) have examined the direct and indirect effects of quality management practices on key results and the relationship between quality practices is identified. To achieve the proposed objective, a structural model is taken from the previous reviews in order to identify the quality practices and causal relationships with the key results. The theoretical model and hypotheses are tested using data collected from a sample of 186 tourist accommodation companies certified with the "Q for Tourist Quality" standard in Spain using EFQM quality practice questionnaire. The methodology consist of the applications related to Exploratory and Confirmatory Factorial Analysis to validate the scales like reliability, one-dimensionality and validity. To define the number of each items with measuring instruments and to test the formulated hypotheses by using SEM technique. The key results shows positive relationship between quality practices and their impact on processes management and quality policy/planning. It is also observed that the quality practices have most influence among key factors like quality policy/planning, leadership and process management.

Abd Rahim Romle, et al., (2016) have investigated the relationship between TQM and the moderating variable Organizational Culture (OC). Many theories have emphasized the necessity to establish the fit between organizations and intended strategies as the first and key success factor. Hence, the relationship between TQM and OC is examined. As known, TQM is a comprehensive and structured approach for organizational management that seeks the quality of products and service improvement through ongoing refinements in response to continuous feedback. TQM can be applied to any type of organization; it originated in the manufacturing sector and adopted in almost every type of organization like schools, highway maintenance, hotel management and more. The study indicates the relationship between TQM and OC. It also refers to the TQM characteristics for changing the product and process design which would create new forms of OC.

Jamaluddin, et al., (2016) have aimed to validate an instrument of Quality Management Practices (QMPs) and performance measurement for the manufacturing industry in Malaysia. The factors considered for measuring QMPs and performance are management commitment, training, process management, quality tools, continuous improvement and organizational performance. From distributed sample of over 480 questionnaires only 210 samples are forced to be valid for analysis. Confirmatory Factor Analysis (CFA) is employed using Analysis of Moment Structures (AMOS) software. The result describes an efficient production system which plays an important role in explaining the competitiveness of the large enterprises and SMEs by using appropriate technology. Thus, a quality management practice and performance framework is needed to help the SMEs in their efforts to become more effective, productive and improve their competitiveness across national and international markets.

Zahari and Zakuan (2016) have analyzed the relationship between TQM and employee performance. A total of 350 questionnaires have been distributed to 10 manufacturing companies in Malaysia and effective usable sample of 294 that is $84 \%$ are obtained. Reliability test is done to test the questionnaire before pilot test with seven critical success factors of TQM like top management participation, customer focus, education and training, information analysis, employee empowerment, human resource development, management policies and strategy. The TQM factors are consider as independent variables and employee performance as dependent variable which is measured through job performance and employee satisfaction. Statistical analysis and regression are used to predict and estimate the relationship. The model is derived from SEM technique using AMOS software. The findings showed that TQM practices have a positive and significant relationship among the variables of employee performance. The study also highlights the significance of people component in the firm's reputation and performance. 


\section{RESEARCH METHODOLOGY}

The main objectives of this paper are:

- To find out the relationship between TQM practices on organizational and employee commitment towards organizational Performance.

- To understand the effect of commitment factors towards organizational performance in selected Auto components manufacturing companies.

\subsection{Research Design}

The study describes about the TQM practices implemented in auto component manufacturing sector with the commitment of employees and management for improving the organizational performance. Further the researcher attempted to find out the relationship between significant variables related to performance and organizational commitment. The significant variables like Management Participation, Teamwork, Employee empowerment, Training and development, Process quality management, Supplier quality, Employee encouragement and quality culture are decided for the study as the factor of TQM practices based on literature review. The study included multiple performance factors namely, employee performance and quality performance.

Descriptive research design is used in this study to describe the attitudes of participants in a systematic way. The primary data are collected from the employees of selected auto component manufacturing companies in Coimbatore region using survey method. The data comprises of 487 respondents from 10 selected auto component companies on the basis of ISO 9000 , TS16949 certification. The questionnaire consists of 8 independent variables with related questions and measures the opinion of respondent in Likert scale. Multistage sampling technique is used to determine the suitable respondent for this study. The purpose of the paper is to understand the relationship and impact of TQM practices on commitment and performance metrics of Auto Component manufacturing companies.

\subsection{Reliability and Validity Analysis}

Table 1 explains reliability and validity analysis for variables consider in this study. The coefficients of Cronbach's alpha were higher than 0.70 , meeting the desirable value recommended by Nunnally and Bernstein (1994). In addition, the analysis calculated composite reliability and according to Bagozzi and Yi (1988), a composite reliability of 0.60 or above is deemed acceptable in assessing the reliability of scales. For this study, all scales were reliable as the Cronbach's alpha values were in a range of $0.728-0.912$, and composite reliability values were between 0.812 and 0.9235 . Convergent validity is established when a measure of a variable produces AVE of 0.50 or higher (Fornell and Larcker, 1981). As showed in Table 1, the average variance extracted (AVE) coefficients of all constructs were in a range of 0.724 0.794 , providing strong evidence of convergent validity.

Table 1 Reliability and Validity analysis

\begin{tabular}{|l|c|c|c|c|}
\hline \multicolumn{1}{|c|}{ Scales } & $\begin{array}{c}\text { No. of } \\
\text { items }\end{array}$ & $\begin{array}{c}\text { Cronbach's } \\
\text { Alpha }\end{array}$ & $\begin{array}{c}\text { Composite } \\
\text { reliability }\end{array}$ & $\begin{array}{c}\text { Average variance } \\
\text { extracted }\end{array}$ \\
\hline Management Participation (MP) & 6 & 0.813 & 0.903 & 0.728 \\
\hline Teamwork (TW) & 6 & 0.87 & 0.878 & 0.761 \\
\hline Employee Empowerment (EE) & 6 & 0.825 & 0.892 & 0.736 \\
\hline Training and Development (TD) & 6 & 0.89 & 0.876 & 0.751 \\
\hline Process Quality Management (PQM) & 6 & 0.829 & 0.864 & 0.746 \\
\hline Supplier Quality Management (SQM) & 6 & 0.728 & 0.815 & 0.757 \\
\hline Employee Encouragement (EEC) & 6 & 0.784 & 0.897 & 0.794 \\
\hline
\end{tabular}


A Structural Relationship between TQM Practices and Organizational Performance with Reference to Selected Auto Component Manufacturing Companies

\begin{tabular}{|l|l|l|l|l|}
\hline Quality Culture (QC) & 6 & 0.876 & 0.860 & 0.789 \\
\hline Organizational Commitment (OC) & 6 & 0.746 & 0.812 & 0.724 \\
\hline Employee Commitment (EC) & 6 & 0.912 & 0.935 & 0.729 \\
\hline Quality Performance (QP) & 6 & 0.897 & 0.846 & 0.759 \\
\hline Employee Performance (EP) & 6 & 0.842 & 0.845 & 0.789 \\
\hline
\end{tabular}

\section{ANALYSIS AND RESULTS}

The present study focuses on various TQM Practices and their influence on commitment and performance variables like employee and quality performance. The study also provides the insights of significant relationship between the variables of commitment and performance through the application of TQM practices with proper and suitable statistical tools. AMOS V.21 is used to construct the model for measuring the influence level of TQM practices on commitment and performance variables.

\subsection{SEM for TQM Practices on Commitment and Performance}

SEM is analyzed through AMOS v2 1 is the extension of multiple linear regression. In multiple linear regression many independent variables are used to measure the impact upon single dependent variable, whereas in SEM the impact of multiple independent variables upon multiple dependent variables are measured. Simultaneously, several equation can be constructed and covariance among the independent variables are also be measured, and hypothesis can also be tested.

The SEM is constructed with the constructs of TQM practices and their effect on organizational commitment, employee commitment, employee performance and quality performance. Furthermore, the covariance that exist among the variables of TQM practices also shows through double sided arrow and its covariance level also mentioned. Even the employee performance and quality performance variables have covariance i.e., performance of employee would have impact on achieving the high quality performance. The following figure 4.6 depicts the SEM for TQM practices on organizational commitment, employee commitment, employee performance and quality performance. It also shows that management participation and teamwork has positive covariance on supplier quality management which explains the direct effect of one variable on the other and employee empowerment on process quality management, training and development on supplier quality management, employee encouragement and quality culture has expressed negative covariance among each other. Process quality management also have negative covariance on employee encouragement and supplier quality management expresses positive covariance with quality culture.

Figure 1 shows the standard regression weight of the different variables and the result of confirmatory factor analysis is obtained, processed and presented in the following table for the respective SEM of TQM practices on organizational commitment, employee commitment, employee performance and quality performance. 


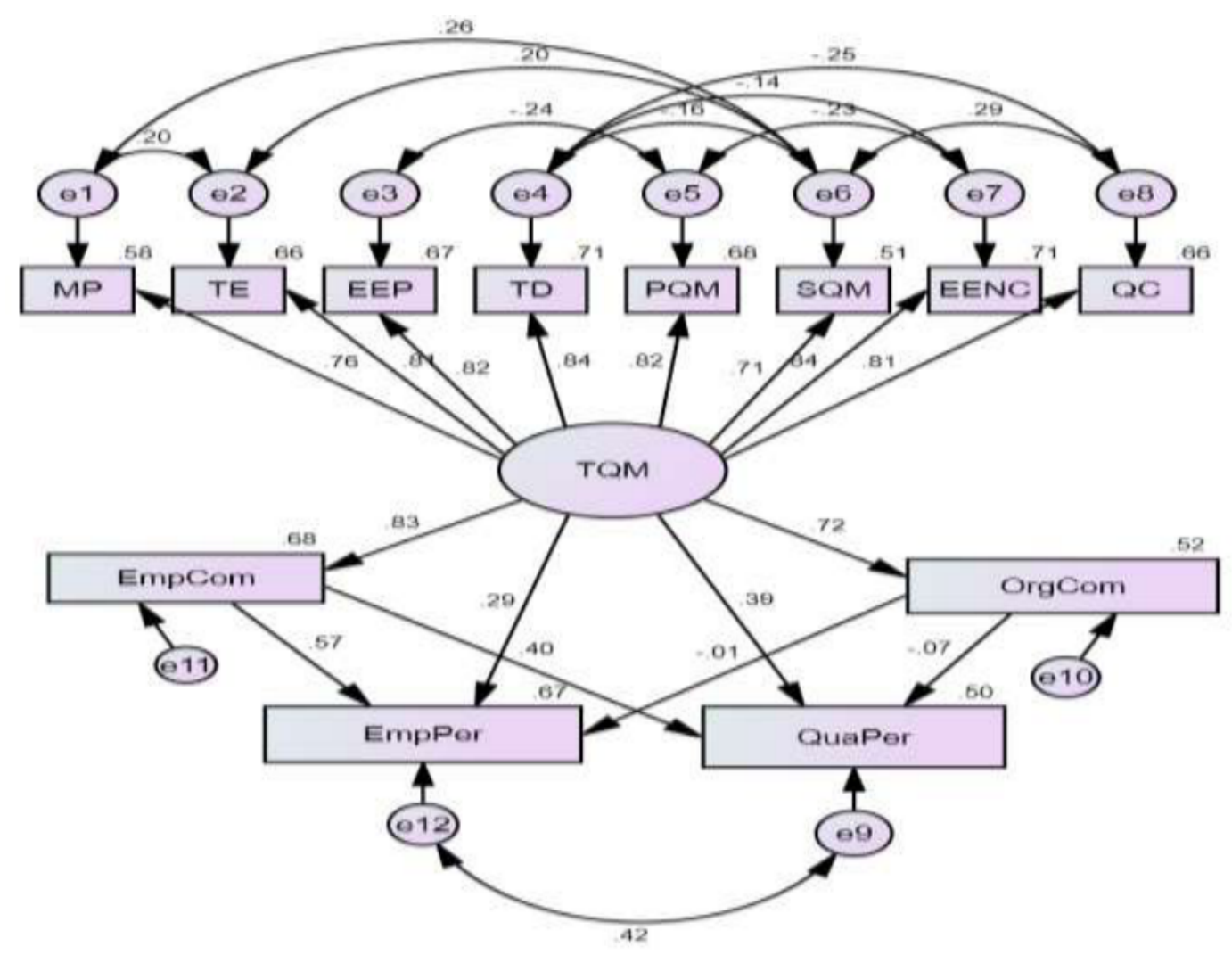

Figure 1 Structural Equation model for TQM practices on commitment and performance

The following table describes the standardized and unstandardized estimates of all the variables taken for the study along with their respective $\mathrm{R}^{2}$ and level of significance.

Table 2 Estimates of TQM Practices on Commitment and Performance

\begin{tabular}{|c|c|c|c|c|c|c|c|c|}
\hline \multicolumn{2}{|c|}{ Factors } & $\begin{array}{c}\text { Standardized } \\
\text { Estimate }\end{array}$ & $\begin{array}{c}\text { Unstandardized } \\
\text { Estimate }\end{array}$ & S.E. & C.R. & P & R $^{2}$ \\
\hline EC & $<---$ & TQM & .826 & .988 & .043 & 22.836 & $* * *$ & .68 \\
\hline OC & $<---$ & TQM & .721 & 1.049 & .054 & 19.416 & $* * *$ & .52 \\
\hline MP & $<---$ & TQM & .765 & 1.000 & & & & .58 \\
\hline TE & $<---$ & TQM & .810 & 1.059 & .042 & 24.941 & $* * *$ & .66 \\
\hline EEP & $<---$ & TQM & .820 & 1.124 & .050 & 22.527 & $* * *$ & .67 \\
\hline TD & $<---$ & TQM & .843 & 1.116 & .048 & 23.176 & $* * *$ & .71 \\
\hline PQM & $<---$ & TQM & .825 & 1.098 & .049 & 22.554 & $* * *$ & .68 \\
\hline SQM & $<---$ & TQM & .714 & 1.003 & .045 & 22.034 & $* * *$ & .51 \\
\hline EENC & $<---$ & TQM & .842 & 1.089 & .047 & 23.047 & $* * *$ & .71 \\
\hline QC & $<---$ & TQM & .811 & 1.051 & .047 & 22.231 & $* * *$ & .66 \\
\hline EP & $<---$ & EC & .566 & .514 & .039 & 13.235 & $* * *$ & .57 \\
\hline QP & $<---$ & EC & .395 & .356 & .047 & 7.550 & $* * *$ & .40 \\
\hline EP & $<---$ & OC & -.007 & -.006 & .025 & -.218 & .827 & \\
\hline QP & $<---$ & OC & -.067 & -.050 & .031 & -1.618 & .106 & \\
\hline EP & $<---$ & TQM & .289 & .314 & .057 & 5.471 & $* * *$ & .67 \\
\hline QP & $<---$ & TQM & .394 & .425 & .070 & 6.076 & $* * *$ & .50 \\
\hline
\end{tabular}

It is evidenced from the above table that all the variables taken for the study significantly contribute towards their respective constructs and explains that the $\mathrm{P}$ value is significant at $99 \%$ 
confidence level. The R square value for the employee commitment contributes to 0.68 which explains $68 \%$ contribution and organizational commitment is 0.52 , with the $52 \%$ of the variation in the implementation of TQM practices, management participation contributes $58 \%$, teamwork contributes $66 \% \mathrm{t}$, employee empowerment contributes to $67 \%$, training and development contributes to $71 \%$, and process quality management contributes $68 \%$, supplier quality management contributes to $51 \%$, employee encouragement contributes to $71 \%$ and quality culture contributes to $66 \%$ towards TQM practices. Further TQM practices towards organizational commitment is affected to the extent of $52 \%$, employee commitment is affected to the extent of $68 \%$, quality performance is affected to the extent of $50 \%$ and employee performance to the extent of $67 \%$ on the whole.

The practice of training and development is the highest influencer of the TQM practices with $b=.843$ followed by employee encouragement with $b=.842$. The third and fourth influencer of the TQM practices are process quality management with $b=.825$ and employee empowerment $(b=.820)$ respectively. Quality culture lies at the fifth place with $b=0.811$ and teamwork stands at the sixth place with $b=0.810$. Management participation is the second least influencer of TQM practices with $b=.765$ and the least influencer of TQM practices is supplier quality management $(b=0.714)$. Employee commitment shows more coefficient than the organizational commitment and quality performance shoes better coefficient value than the employee performance based on influence of TQM practices. Employee commitment has beta value .566 for employee performance and .395 for quality performance. Organizational commitment shows the negative coefficient value for both employee performance and quality performance.

Table 3 exhibits the hypotheses such as TQM practices do not influence the employee commitment, organizational commitment, employee performance and quality performance and employee commitment do not have any influence on employee performance and quality performance and also organizational commitment do not have influence on employee performance and quality performance and the validity of the hypotheses is also being tested and displayed the result.

Table 3 Hypothesis testing for TQM Practices on Commitment and Performance

\begin{tabular}{|c|c|c|l|c|c|c|}
\hline \multicolumn{2}{|c|}{ Factors } & \multicolumn{1}{|c|}{ Hypothesis } & $\mathbf{R}^{2}$ & P & Inference \\
\hline TQM & $\leftarrow$ & EC & $\begin{array}{l}\text { TQM Practices does not influence Employee } \\
\text { Commitment }\end{array}$ & .68 & .000 & Rejected \\
\hline TQM & $\leftarrow$ & OC & $\begin{array}{l}\text { TQM does not influence Organizational } \\
\text { Commitment }\end{array}$ & .52 & .000 & Rejected \\
\hline TQM & $\leftarrow$ & EP & $\begin{array}{l}\text { TQM Practices does not influence Employee } \\
\text { Performance }\end{array}$ & .67 & .000 & Rejected \\
\hline TQM & $\leftarrow$ & QP & $\begin{array}{l}\text { TQM Practices does not influence Quality } \\
\text { Performance }\end{array}$ & .50 & .000 & Rejected \\
\hline EC & $\leftarrow$ & EP & $\begin{array}{l}\text { Employee Commitment does not influence } \\
\text { Employee Performance }\end{array}$ & & .000 & Rejected \\
\hline EC & $\leftarrow$ & QP & $\begin{array}{l}\text { Employee Commitment does not influence } \\
\text { Quality Performance }\end{array}$ & & .000 & Rejected \\
\hline OC & $\leftarrow$ & EP & $\begin{array}{l}\text { Organizational Commitment does not } \\
\text { influence Employee Performance }\end{array}$ & & .827 & Accepted \\
\hline OC & $\leftarrow$ & QP & $\begin{array}{l}\text { Organizational Commitment does not } \\
\text { influence Quality Performance }\end{array}$ & & .106 & Accepted \\
\hline
\end{tabular}

From the above table, it is observed that the $\mathrm{P}$ value shows significant result which is less than .01 and explains that the stated hypothesis is rejected at $1 \%$ level of significance for the variables of TQM practices on organizational commitment, employee commitment, employee 
performance and quality performance. Further, the hypotheses framed for employee commitment influence on employee performance and quality performance is also rejected because significant $\mathrm{P}$ value which is less than .01 at $1 \%$ level of significance. Again, the hypotheses framed for organizational commitment influence on employee performance and quality performance is accepted because of insignificant $\mathrm{P}$ value which is more than .01 under $1 \%$ level of significance.

It is concluded that, TQM practices like management participation, teamwork, employee empowerment, training and development, process quality management, supplier quality management, employee encouragement and quality culture significantly influences the organizational commitment, employee commitment, employee performance and quality performance. In turn employee commitment on the implementation of TQM practices have significantly influences on employee performance and quality performance but the organizational commitment does not have significant influence on employee performance and quality performance.

\section{CONCLUSION}

The findings of this study contribute to the implementation of TQM in auto component manufacturing companies through literatures and reports from ACMA. Initially, a valid and reliable instrument is developed and used to measure the TQM practices in auto component manufacturing sector. Second, the research is documented to understand the influence level of TQM practices on the factors of commitment and performance in auto component manufacturing organizations utilized quality certification and standards. As stated earlier, there is only few information is available in the current literature on TQM implementation in Indian auto component sector especially southern cluster. This study also contribute to the extent of theory and nature of quality management practices followed in auto component manufacturing companies. The results may vary to a certain extent between groups and significant difference is found on seven critical success factors of TQM and two performance indicators.

\section{REFERENCES}

[1] Abd Rahim Romle, et al., the Effects of TQM Practices on Organizational Culture: A New Movement, World Applied Sciences Journal, 34(5), 2016, pp 53-560.

[2] Abd Rahim Romle, Razli Che Razak, and Abdul Shukor Shamsudin, Mapping the Relationships between Quality Management Practices, Human-Oriented Elements and Organizational Performance: A Proposed Framework, International Journal of Innovation, Management and Technology, 6(3), 2015, pp 196-201.

[3] Cemal Zehira, et al, Total Quality Management Practices' Effects on Quality Performance and Innovative Performance, 41(1), 2012, pp 273 - 280.

[4] R.Jeyalakshmi and G.Thamarai Selvi, Effect of TQM Practices in Large and Small Medium Electronic Companies in Tamil Nadu, International Journal of Mechanical Engineering and Technology, 9(4), 2018, pp. 802-808.

[5] Esam M. A.Mustafa and Abdul Talib Bon, Role of top management leadership and commitment in total quality management in service organization in Malaysia: A review and conceptual framework, Elixir Human Resource Management, 51(1), 2012, pp 11029-11033.

[6] B. Al Mannai, S.M.A. Suliman and Y. Al Alawai, An Investigation into the Effects of the Application of TQM, TPM and JIT on Performance of Industry in Bahrain, International Journal of Industrial Engineering Research and Development, 8(1), 2017, pp. 09-19. 
A Structural Relationship between TQM Practices and Organizational Performance with Reference to Selected Auto Component Manufacturing Companies

[7] Faisal Talib, Zillur Rahman and M.N. Qureshi, Pareto Analysis of Total Quality Management Factors Critical to Success for Service Industries, International Journal of Quality Research, 4 ( 2), 2010, pp 155-168.

[8] Isaac A. Ayandele and Anietie P. Akpan, The Practice, Challenges and Benefits of Total Quality Management (TQM) In Manufacturing Firms in Nigeria, International Journal of Economic and Business Management, 3(5), 2015, pp 62-74.

[9] B. Al Mannai, S. Suliman and Y. Al Alawai, TQM Implementation Effect on Bahrain Industrial Performance, International Journal of Industrial Engineering Research and Development, 7(2), 2016, pp. 75-81.

[10] Ismah Osman, Husniyati Ali, Wan Edura Wan Rashid, Kamauzaman Jusoff, Total Quality Management in the Malaysian Automobile Industry, International Business Research, 2 ( 2), 2009, pp 203-20

[11] José Álvarez García, María de la Cruz del Río Rama and Mercedes Vila Alonso ,The Effects of Quality Management Practices on Key Results: questionnaires sample for the industry of tourist accommodation in Spain, Revista Brasileira De Gestão De Negócios Review of Business Management, 16( 52), 2014, pp 351-373.

[12] Rula Ali Al-Damen, The impact of Total Quality Management on organizational performance Case of Jordan Oil Petroleum Company, International Journal of Business and Social Science, 8 (1), 2017, pp 192-202.

[13] B. Al Mannai, S.M.A. Suliman and Y. Al Alawai, An Investigation into the Effects of the Application of TQM, TPM and JIT on Performance of Industry in Bahrain, International Journal of Industrial Engineering Research and Development, 8(1), 2017, pp. 09-19.

[14] Shekoufeh Nekoueizadeh and Siavash Esmaeili, A study of the impact of TQM on organizational performance of the Telecommunication Industry in Iran, European Online Journal of Natural and Social Sciences, 2(3), 2013, pp 968-978.

[15] Varsha Dixit and Monika Bhati, A Study about Employee Commitment and its impact on Sustained Productivity in Indian Auto-Component Industry, European Journal of Business and Social Sciences, 1(6), 2012, pp $34-51$.

[16] Zaharuzaman Jamaluddin, Ahmad Mahir Razali, Zainol Mustafa \& Mohd Rashid Ab Hamid , Quality Management Practices and Performance Measurement in the Manufacturing Industry: An Instrument Validation, Sains Malaysiana, 45 (6), 2016,pp 999-1006. 